\title{
Front Line Demonstration (FLD) on Integrated Crop Management Practices in Brinjal
}

\author{
C. Rajamanickam* \\ Department of Horticulture, Agricultural College and Research Institute, Madurai, India \\ *Corresponding author
}

\section{Keywords}

Brinjal,

Demonstration,

Yield, Farmers

practice, Net returns

Article Info

Accepted:

16 November 2020

Available Online:

10 December 2020

\section{A B S T R A C T}

Brinjal (Solanum melongena L.) is an important vegetable crop occupies more areas in India. In Tamil Nadu it is cultivated in Dindigul, Coimbatore, Madurai, Ramanathapuram, Virudhunagar, Vellore, Salem, Tirunelveli and Krishnagiri districts in larger areas. Vegetable crops were cultivated in 2000 ha area and it is being cultivated in Kamuthi, Paramakudi, Bogalur and Nainarkoil blocks of Ramanathapuram district. Farmers were cultivated local varieties, adopted local technologies, getting low income, low yield and unaware new technologies for cultivation of brinjal. With this background, Front Line Demonstration (FLD) on "Integrated Crop Management (ICM) practices in brinjal" was carried out by Krishi Vigyan Kendra, Ramanathapuram at farmers' field during the year 2017-18 with the aim to study the extent of adoption of integrated crop management in brinjal, to study the yield and economics of brinjal production and doubling the farmers' income. Demonstration was carried out at Bogalur, Mandapam and Nainarkoil blocks of Ramanathapuram district with two ha area and conducted ten demonstrations. Inputs like arka vegetable special, neem soap, Pseudomonas fluoresences, Wota - T traps and yellow sticky traps were purchased and distributed to the ten identified farmers. Front Line Demonstration results revealed that demonstration plots recorded the highest values in growth characters viz., plant height $(42.15 \mathrm{~cm})$, number of fruits per plant $(51.0)$ and average fruit weight $(62.5 \mathrm{~g})$ while farmer practices registered the lowest values in all the vegetative traits. Regarding yield characters, demonstrated practices recorded the highest yield per ha $(19.12 \mathrm{t} / \mathrm{ha})$, yield per plant $(3.13 \mathrm{~kg})$, net returns $(\mathrm{Rs} .1,18,700)$ with the cost benefit ratio of 3.22. Whereas farmer practices (local practices) registered the lowest yield $(15.32 \mathrm{t} / \mathrm{ha})$, yield per plant $(2.25 \mathrm{~kg})$, net returns (Rs. 80,100) and cost benefit ratio of 2.38. Regarding shoot and fruit borer and aphids incidences, demonstrated plot recorded very low incidence $(5.23 \% ; 4.05 \%)$ whereas farmers practices noticed higher incidence $(19.50 \% ; 11.66 \%)$ of both the insects. Adoption of new technology increased the yield of 24 per cent over the farmer practices.

\section{Introduction}

Brinjal (Solanum melongena L.) is an important indigenous vegetable crop of India and occupies an area of 7.11 lakh hectares with production of 135.58 lakh tonnes as well as productivity of $19.10 \mathrm{t} / \mathrm{ha}$ in India. It contributes 9 per cent total vegetable 
production of the country. Tamil Nadu, West Bengal, Odisha, Gujarat, Madhya Pradesh, Bihar, Chhattisgarh, Andhra Pradesh and Karnataka are leading states in brinjal cultivation in India. In Tamil Nadu brinjal is cultivated in an area of 13475 ha and production of $103.7 \mathrm{t}$ during 2015-16 and cultivated in districts like Dindigul, Dharmapuri, Cuddalore, Coimbatore, Madurai, Ramanathapuram, Villupuram, Vellore, Salem, Tirunelveli, Kanyakumari and Krishnagiri in larger areas. Vegetable crops were cultivated in an area of 2000 ha in Ramanathapuram district and it is being cultivated in Kamuthi, Paramakudi, Bogalur and Nainarkoil blocks.

Farmers were cultivated local varieties, adopted local technologies, getting low income, low yield and unaware new technologies for cultivation of brinjal. Improvement of production technology, protection measures and genetic improvement has resulted significant advancement in yield, quality and pest and disease management. With this background, Front Line Demonstration (FLD) on "Integrated Crop Management (ICM) practices in brinjal" was carried out at Krishi Vigyan Kendra, Ramanathapuram at farmers' field during the year 2017-18 with the aim to study the extent of adoption of integrated crop management in brinjal, to study yield gap identified in brinjal production in Ramanathapuram district and yield and economics of brinjal production and doubling the farmers' income. Keeping in view, an effective extension approach of frontline demonstrations for dissemination of integrated crop management of brinjal production in Ramanathapuram district at farmers field.

\section{Materials and Methods}

The frontline demonstrations were conducted on integrated crop management (ICM) in brinjal at farmer's field of Ramanathapuram district, Tamil Nadu during the year $2017-18$. Demonstration was carried out at Bogalur, Mandapam and Nainarkoil blocks of Ramanathapuram district with two ha area and conducted ten demonstrations. The critical inputs were supplied to farmers and applied as per the recommended package of practices for brinjal crop (Crop production guide, 2013).

Demonstrations at farmer's fields were regularly monitored by scientists of Krishi Vigyan Kendra from sowing to harvesting and marketing. Seeds of brinjal var. $\mathrm{CO} 2$ were purchased from Horticultural College and Research Institute, Tamil Nadu Agricultural University, Coimbatore and distributed to the farmers. Inputs like arka vegetable special, neem soap, Pseudomonas fluoresences, Wota - $\mathrm{T}$ traps and yellow sticky traps were purchased and distributed to the ten identified farmers. Foliar spray of arka vegetable special @ 3g in 1 litre of water was applied during critical periods like pre flowering, flowering and fruit developments stages. Yellow sticky traps @ 15 numbers per acre were placed in different directions of the plot. Neem soap @ $10 \mathrm{~g}$ per litre of water (200 litres of spray solution per ha) were applied as foliar spray to control the whitefly activity. Wota - T traps @ five numbers per acre were placed different directions of the demonstrated plot to control the shoot and fruit borer moths. Biometric observations on plant height, number of fruits per plant, average fruit weight, yield per plant, estimated yield per ha, incidence of shoot and fruit borer, aphids incidence, net returns and cost benefit ratio were made. The information on demonstrated package of practices and farmers' practices for ICM in brinjal are presented in Table 1. The data were analysed with appropriate statistical method was suggested by Panse and Sukhatme (1985). 


\section{Results and Discussion}

\section{Vegetative parameters}

The present front line demonstration of vegetative and yield traits are presented in Table 2. The results revealed that demonstrated practices recorded the highest values in growth characters viz., plant height $(42.15 \mathrm{~cm})$, number of fruits per plant (51.0) and average fruit weight $(62.5 \mathrm{~g})$. Whereas farmer practices registered the lowest values of all the vegetative traits viz., plant height $(38.25 \mathrm{~cm})$, number of fruits per plant (42.0) and average fruit weight $(54.0 \mathrm{~g})$. This was in conformity with the findings of Tamilselvan et al., (2017) reported that demonstrated plot registered the highest plant height and fruit weight in brinjal when compared with local check in Nagapatinam district. Prabhu et al., (2016) also stated that demonstrated plot recorded that highest plant height when compared with farmers practices in brinjal at Vellore district.

Table.1 Demonstrated package of practices and farmers practice for ICM in brinjal

\begin{tabular}{|c|c|c|c|}
\hline $\begin{array}{l}\text { Sl. } \\
\text { No. }\end{array}$ & Package of practices & $\begin{array}{c}\text { Frontline demonstration (Demonstrated } \\
\text { package) }\end{array}$ & $\begin{array}{l}\text { Farmers practice } \\
\text { (Local check) }\end{array}$ \\
\hline 1. & $\begin{array}{l}\text { Selection of high yielding } \\
\text { variety /hybrid }\end{array}$ & Brinjal var. CO-2 variety @ 500g & $\begin{array}{l}\text { Local or unknown private } \\
\text { hybrid/variety, no information. }\end{array}$ \\
\hline 2. & Seed treatment & $\begin{array}{l}\text { Seed treated with Pseudomonas fluorescens } \\
\text { @ } 10 \mathrm{~g} \text { per kg of seeds. }\end{array}$ & Not known \\
\hline 3. & $\begin{array}{l}\text { Raising the seedling in } \\
\text { nursery }\end{array}$ & $\begin{array}{l}\text { Pro-tray method of raised seedling in } 50 \% \\
\text { shade nethouse and covers sides with } 50 \\
\text { mesh insect proof nylon net and selected } \\
\text { good quality seedling. }\end{array}$ & $\begin{array}{l}\text { Purchased seeds and raised in the } \\
\text { nursery beds after eight weeks } \\
\text { seedling transplanted in to the } \\
\text { mainfield. }\end{array}$ \\
\hline 4. & $\begin{array}{l}\text { Spacing } \\
\text { spacing }\end{array}$ season and & Rabi (October to February) $60 \mathrm{~cm} \mathrm{x} 60 \mathrm{~cm}$ & $\begin{array}{l}\text { Rabi (October to February) } 45 \mathrm{~cm} \mathrm{x} \\
60 \mathrm{~cm}\end{array}$ \\
\hline 5. & $\begin{array}{l}\text { Application of farm yard } \\
\text { manure (Approximately) }\end{array}$ & $\begin{array}{l}\text { Applied farmyard manure } 25 \mathrm{t} / \mathrm{ha} \text { at the } \\
\text { time ploughing and incorporated into the } \\
\text { soil. Ridges and furrows preparation. } \\
\text { Pseudomonas fluorescens @ } 2.5 \mathrm{~kg} \text { applied } \\
\text { during last ploughing. }\end{array}$ & $\begin{array}{l}\text { Applied farmyard manure three } \\
\text { tractor load or } 15 \text { t/ha last ploughing } \\
\text { and ridges and furrow preparation } \\
\text { for transplanting. }\end{array}$ \\
\hline 6. & $\begin{array}{l}\text { Application } \\
\text { recommended } \\
\text { dose of fertilizer }\end{array}$ & $\begin{array}{l}\text { After transplanting, applied } 110 \mathrm{~kg} \mathrm{~N}+300 \\
\mathrm{~kg} \mathrm{P} 2 \mathrm{O} 5+50 \mathrm{~kg} \mathrm{K2O} \mathrm{per} \mathrm{ha} \mathrm{(blanket} \\
\text { recommendation of NPK 50:50:30 kg/ha). } \\
\text { Top dressing : } 50 \mathrm{~kg} \text { Nitrogen } / \mathrm{ha} \text { on } 30 \mathrm{th} \\
\text { day of planting or during earthing up. }\end{array}$ & $\begin{array}{l}\text { After transplanting, applied } \\
\text { 19:19:19 NPK complex fertilizers or } \\
\text { 20:20:0 NPK mixed chemical } \\
\text { fertilizer (Approx. 10-15 g/plant) 2- } \\
3 \text { times during cropping period. }\end{array}$ \\
\hline 7. & $\begin{array}{l}\text { Application of vegetable } \\
\text { Special / micro-nutrient }\end{array}$ & $\begin{array}{l}\text { Foliar spray of vegetable special @ } 5 \mathrm{~g}+1 \\
\text { litre of water }+ \text { sticking agents at vegetative } \\
\text { stage, flowering and fruit development } \\
\text { stages. }\end{array}$ & $\begin{array}{l}\text { Not applied any micro-nutrients } \\
\text { spray. }\end{array}$ \\
\hline 8. & Irrigation & $\begin{array}{l}\text { Furrow method of irrigation once in four } \\
\text { days or once in a week. }\end{array}$ & $\begin{array}{l}\text { Furrow method of irrigation once in } \\
\text { four days or once in a week. }\end{array}$ \\
\hline 9. & Application of neem cake & $\begin{array}{l}\text { Neem cake @ } 250 \mathrm{~kg} / \mathrm{ha} \text {, two split - at the } \\
\text { time of transplanting and } 30 \text { days after } \\
\text { planting. }\end{array}$ & Not applied any neem cake. \\
\hline 10. & $\begin{array}{l}\text { Plant protection measures } \\
\text { for control of insect pest }\end{array}$ & $\begin{array}{l}\text { Need based application of plant protection } \\
\text { like bio-pesticides and chemical for control: }\end{array}$ & $\begin{array}{l}\text { Not followed, } \begin{array}{r}\text { Indiscriminate } \\
\text { spraying of pesticides and }\end{array}\end{array}$ \\
\hline
\end{tabular}




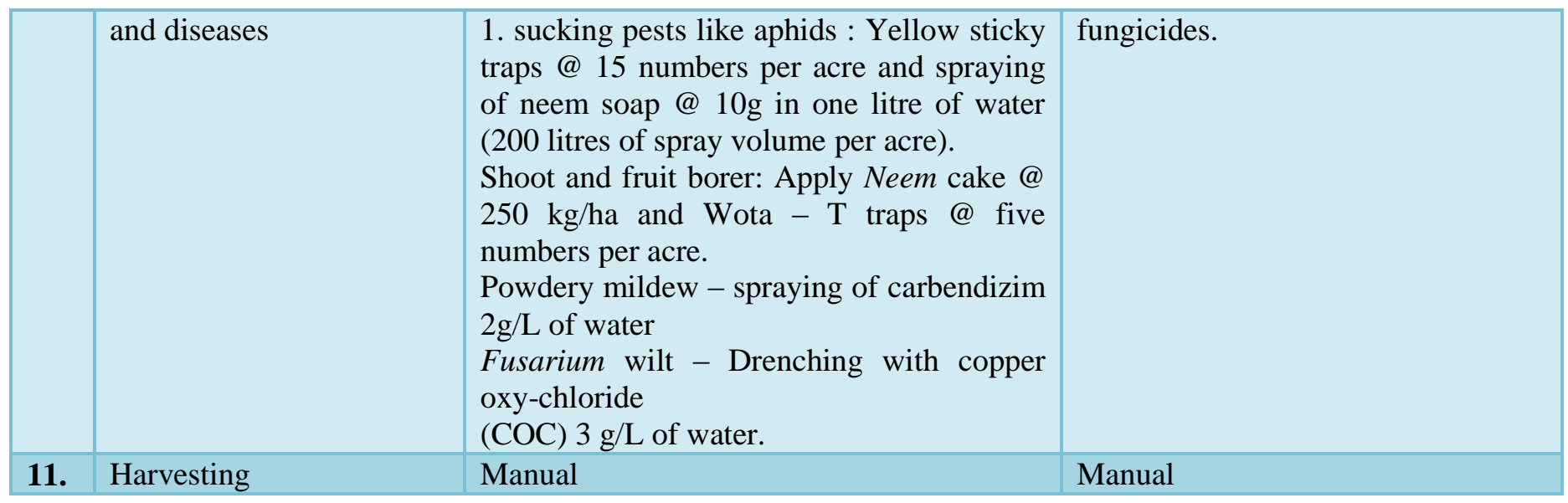

Table.2 Demonstration and farmers practices of ICM practices in brinjal cv. CO2

\begin{tabular}{|l|l|c|c|}
\hline Sl. No. & \multicolumn{1}{|c|}{ Particulars } & ICM in brinjal & Local check \\
\hline 1. & Plant height $(\mathrm{cm})$ & $42.15 \mathrm{~cm}$ & $38.25 \mathrm{~cm}$ \\
\hline 2. & No. of fruits per plant & 51.0 & 42.0 \\
\hline 3. & Average fruit weight $(\mathrm{g})$ & $62.0 \mathrm{~g}$ & $54.0 \mathrm{~g}$ \\
\hline 4. & Yield per plant $(\mathrm{g})$ & $3150.0 \mathrm{~g}$ & $2250.0 \mathrm{~g}$ \\
\hline 5. & Estimated yield per ha (t/ha) & 19.12 & 15.32 \\
\hline
\end{tabular}

Table.3 Yield of brinjal before and after frontline demonstration

\begin{tabular}{|c|c|c|c|}
\hline SI. No. & $\begin{array}{c}\text { Before FLD (Farmers } \\
\text { practice) }\end{array}$ & $\begin{array}{c}\text { After FLD (Demonstrated } \\
\text { practices) }\end{array}$ & Yield gap \\
\hline 1. & $15.32 \mathrm{t} / \mathrm{ha}$ & $19.12 \mathrm{t} / \mathrm{ha}$ & $24 \%$ \\
\hline
\end{tabular}

Table.4 Pest incidences of demonstration and farmers practices in brinjal cv. $\mathrm{CO} 2$

\begin{tabular}{|l|l|c|c|}
\hline Sl. No. & \multicolumn{1}{|c|}{ Particulars } & ICM in brinjal & Local check \\
\hline 1. & Shoot and fruit borer incidence & $5.23 \%$ & $19.50 \%$ \\
\hline 2. & Aphids incidence & $4.05 \%$ & $11.66 \%$ \\
\hline
\end{tabular}

Table.5 Economics of demonstration and farmers practices in brinjal cv. CO2

\begin{tabular}{|l|l|c|c|}
\hline Sl. No. & \multicolumn{1}{|c|}{ Particulars } & ICM in brinjal & Local check \\
\hline 1. & Gross cost (Rs.) & 53,400 & 57,750 \\
\hline 2. & Gross income (Rs.) & $1,72,100$ & $1,37,850$ \\
\hline 3. & Net Returns (Rs.) & $1,18,700$ & 80,100 \\
\hline 4. & BCR & 3.22 & 2.38 \\
\hline
\end{tabular}

\section{Yield parameters}

Yield characters of the present demonstrations are presented in Table 1. Regarding yield characters, demonstrated practices recorded the highest yield per plant $(3.13 \mathrm{~kg})$ and yield per ha (19.12 t/ha) whereas the farmers practice registered the lowest values in yield 
per plant $(2.25 \mathrm{~kg})$ and yield per ha (15.32 t/ha). This is in accordance with conformity of Tamilselvan et al., (2017) reported that ICM practiced plot registered the highest yield of $16.05 \mathrm{t} /$ ha compared with control and also 20 per cent yield enhanced while adopting new technologies in brinjal cultivation at Nagapatnum district. Prabhu et al., (2016) reported that demonstrated plot recorded that highest yield of $35.08 \mathrm{t} / \mathrm{ha}$ when compared with farmers practices of $29.42 \mathrm{t} / \mathrm{ha}$ in brinjal at Vellore district. Desai, (2018) reported that demonstrated plot registered the highest yield of $37.95 \mathrm{t} / \mathrm{ha}$ while local check was in 27.80 t/ha in Tumkur district of Karnataka. Rameshkumar et al., (2017) reported that ICM practiced plot registered highest yield per ha and 20 per cent increased yield than farmers practice in water melon. The same results were also reported by Hemalatha et al., (2017) in chilli.

Yield of before and after front line demonstrations are presented in Table 3. Integrated crop management practiced (demonstrated) plot registered 24 per cent over the farmer practices. This might be due to adoption of new production technologies and high yielding varieties. This was in conformity with the findings of Tamilselvan et al., (2017) reported that ICM practiced plot registered 20 per cent yield enhancement when compared with local check. Desai (2018) stated that yield of brinjal per hectare increased by 36.51 per cent in FLD plots.

Pest incidences of present demonstrations are presented in Table 4. In the case of shoot and fruit borer incidence, demonstrated plot recorded the lowest incidence of 5.23 per cent while the highest incidence was noticed in local check $(19.50 \%)$. In the case of aphids incidence, the same trend was noticed. Demonstrated plot registered the lost incidence of aphid $(4.05 \%)$ while the highest incidence was recorded in local check of
11.66 per cent. This might be due to placement of traps and periodical control of pest incidences in the field as well as varietal characters.

\section{Economics}

Economics of the present demonstrations are presented in Table 5. Demonstrated practices (ICM practices) recorded the highest net returns of Rs. 1,18,700 while local check (farmer practices) registered the lowest net returns of Rs. 80,100. Regarding benefit cost ratio, the same trend was noticed. ICM demonstrated plot registered the highest ratio of 3.22 whereas the lowest benefit cost ratio was found in local check of 2.38. This might be due to higher adoption of all the package of practices recommended for brinjal cultivation in the region. It was evident from the results of Desai (2018) reported that B:C ratio for before FLD was 2.12, which was increased to 2.97 after FLD. The same trend was noticed by Prabhu et al., (2016) stated that demonstrated plot registered the higher cost benefit ratio of 2.86 and 19.2 per cent increased yield over the local check in brinjal at Vellore district. Rameshkumar et al., (2018) reported that that demonstrated plot registered the higher cost benefit ratio of 2.57 whereas local check registered the lowest ratio of 2.23 in cashew in Cuddalore district.

In conclusion the frontline demonstration was effective changing of farmers towards the adoption of integrated crop management in brinjal production. Most of the farmers became aware about recommended production practices of brinjal after conducting the frontline demonstration on farmers field. More number of farmers were found to increase in adoption per cent of package of practices such as raising and selection of quality seedling from nursery, selection of high yielding variety, application of vegetable special, placement of traps, 
application of neem soap etc after conduct of FLD as compared to before FLD. Demonstrated plot recorded the highest yield per ha of $19.12 \mathrm{t} / \mathrm{ha}$ and net returns of Rs. $1,18,700$ with benefit cost ratio of 3.22 when compared with local check. The adoption of ICM practices, demonstrated plot increased $24 \%$ over the farmers' practices. The concept of frontline demonstration may be applied to all farmer categories including progressive farmers for speedy and wider dissemination of the recommended practices to other members of the farming community.

\section{References}

Desai, N., Patil, C and B. Mamatha. (2018). Effect of integrated crop management on brinjal yield and economics through frontline demonstration at farmers field. Internat. J. agric. Sci., 14 (1): 154-159.

Hemalatha, K.J., Anandkumar, V, Yenjerappa, S.T. and Ravishankar, G. (2017). Integrated crop management in chilli. A research abstract presented in $2^{\text {nd }}$ KVK Symposium on Frontline Extension Programmes for Realizing Higher Productivity and Profitability in Farming organized by ATARI, Bengaluru and TNAU, Coimbatore on $7-8$ March, 2017 at TNAU, Coimbatore, pp. $43-44$.

Panse, V.G. and Sukhatme, P.V. (1985). Statistical Methods for Agricultural Workers. Second Edition. Indian Council of Agricultural Research, New Delhi, p. 356.

Prabhu, T., Pandiyan, M. and Sridhar, P. (2016). High yielding spiny brinjal and its impact in Vellore district. A research abstract presented in $1^{\text {st }}$ KVK Symposium on Technology delivery mechanisms of KVKs for higher productivity and profitability in Agriculture organized by ATARI, Bengaluru and UAS, Dharwad on $21-22$, January, 2016 at UAS, Dharwad, Coimbatore, pp. 34.

Rameshkumar, A, Sharavanan, P.T, Porkodi, G. and Kannan, S. (2018). Demonstration of crop management practices to increase yield in cashew. A research abstract presented in International Conference on Invigorating transformation of farm extension towards sustainable development: Futuristic challenges and prospects (INTFES - 18) organized by Extension Education Society, TNAU, Coimbatore on $9 \& 10$ March, 2017 at TNAU, Coimbatore, pp. 245.

Rameshkumar, A, Natarajan, K, Kannan, S. and Aneesarani, M.S. (2017). Demonstration of integrated crop management practices in watermelon. A research abstract presented in $2^{\text {nd }}$ KVK Symposium on Frontline extension programmes for Realizing Higher Productivity and profitability in Farming organized by ATARI, Bengaluru and TNAU, Coimbatore on $7-8$ March, 2017 at TNAU, Coimbatore, pp. $64-65$.

Tamilselvan, M, Ravi. R. and Anuratha, A. (2017). Effect of micronutrient mixtures for increasing the yield and productivity in brinjal. A research abstract presented in $2^{\text {nd }}$ KVK Symposium on Frontline extension programmes for Realizing Higher Productivity and profitability in Farming organized by ATARI, Bengaluru and TNAU, Coimbatore on $7-8$ March, 2017 at TNAU, Coimbatore, pp. 49 - 50.

\section{How to cite this article:}

Rajamanickam, C. 2020. Front Line Demonstration (FLD) on Integrated Crop Management Practices in Brinjal. Int.J.Curr.Microbiol.App.Sci. 9(12): 2266-2271.

doi: https://doi.org/10.20546/ijcmas.2020.912.268 